\title{
Perception and Attitude of Employers toward Distance Learning Graduates in Labour Market: A Case Study of Niger State, Nigeria
}

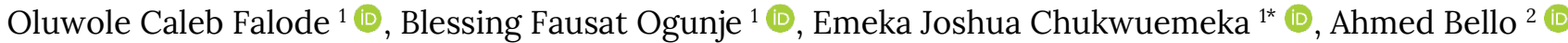

${ }^{1}$ Department of Educational Technology Federal University of Technology, Minna, Niger State, NIGERIA

${ }^{2}$ Department of Science Education, Federal University Kashere, Gombe State, NIGERIA

*Corresponding Author: emekac.joshua@gmail.com

Citation: Falode, O. C., Ogunje, B. F., Chukwuemeka, E. J., \& Bello, A. (2021). Perception and Attitude of Employers toward Distance Learning Graduates in Labour Market: A Case Study of Niger State, Nigeria. European Journal of Interactive Multimedia and Education, 2(1), e02101. https://doi.org/10.30935/ejimed/9348

\begin{abstract}
This study investigated the perception and attitude of employers of labour toward distance learning graduates in Niger State, Nigeria. The descriptive survey research approach was adopted and employers of labour in both private and public sectors within the study area constituted the sample. Four research questions and two null hypotheses were answered and tested respectively in the study. A 19-item researchers' developed questionnaire was used as an instrument for data collection. The instrument was considered suitable after undergoing experts' validation and reliability checks. Data gathered were analyzed in which Mean and Standard Deviation were used to provide answers to the four research questions while t-test statistics were used to test the two hypotheses. Findings revealed that both the perception and attitude of respondents were positive toward distance learning graduates. Based on these findings, it was recommended among others that the government should expand the existing ODL and establish more new ones to reduce the load on conventional institutions and curtail the problem of access to Higher Education in Nigeria.
\end{abstract}

Keywords: distance learning, employers of labour, perception, attitude, graduates

Received: 28 Jul. 2020 • Accepted: 5 Oct. 2020

\section{INTRODUCTION}

Education is the bedrock of all human sectors. It is used as an instrument of change and modernization of dynamic societies. To achieve the envisage modernization, Bukaliya and Mubika (2014) stated that trained manpower with positive attitude toward change has to occupy a rightful position to enhance the growth of that society. For instance, the trained engineers, teachers, medical doctors, administrators, accountants and lawyers should be fixed in ministries and parastatals that fit their specialization. Though having enough quality manpower to fill the available vacancies in ministries and parastatals are still a challenge for employers in Nigeria. For this reason, the National Policy on Education specified the role of higher education (HE) as that of training high level manpower in all fields of human endeavour to occupy available job positions and prepare its graduates for self-reliance, national utility and future opportunities (FRN, 2013). In Nigeria, Higher Education entails post-secondary education acquired at Universities, Polytechnics, Colleges of Education, as well as institutes that prepare candidates for professional courses. These institutions provide highly specialized training courses adapted to the needs of economic and social life of its citizens to satisfy the vision of Nigeria which recognises education as a public good, a fundamental human right that should be inclusive and equitable. The vision is also in line with UNESCO, (2016) provisions which require that HE be open to all so as to cater for the various aspects of lifelong education in the widest sense. In compliance to the National policy and the countries' vision, HE institutions trained graduates in both character and learning for the development of quality manpower.

Conversely, with the increasing population explosion in Nigeria, the available HE institutions do not seem to enroll the teeming applicants, thus, limiting the number of enrollees to the available infrastructures (carrying capacities). Adamu (2017) remarked on HE carrying capacities as overstretching the available infrastructure with double the number of users from which it was designed for. This is manifested in form of admitting a large number of students beyond the carrying capacity of lecture halls, classrooms, lecturer-students' ratio, students' hostels, libraries and ICT laboratories. While these could portray infrastructural challenges perpetrated by increasing demography, it had denied many an opportunity to access HE while significant others remained vulnerable to low profile jobs (Rahman, 2014). With the advent and integration of Information and Communication Technology (ICT) in education, the delivery of higher education shifted from conventional schooling to ICT-enabled learning in form of distance education.

Distance education is a formal education system that deploys ICT facilities to accelerate teacher-students' interaction and ensure 
productive learning among students who are domiciled in distant locations. It is increasingly being accepted as a standard of educational delivery worldwide because, it's viable and flexible without sacrificing quality. It also provides an opportunity for students to get course materials in different formats (text, image, sound, video, animations, etc.), and can interact with their colleagues and lecturers individually and simultaneously via message boards (Papadakis et al., 2019). The coming of distance education to Nigeria is like a messiah that levelled the ground for all including those from remote locations, disadvantaged families, women, physically challenged and internally displaced persons to access HE. Thus, prestigious institutions in Nigeria like National Open University of Nigeria (NOUN) with student enrolment of over 400,000 as of July 2017, with other similar universities like University of Ibadan, Ibadan; Obafemi Awolowo University of Ile-Ife; University of Lagos, Akoka; University of Maiduguri, Maiduguri; Modibo Adama University of Technology, Yola; University of Abuja, Abuja; Ladoke Akintola University of Technology, Ogbomoso; and Ahmadu Bello University, Zaria has been on race to providing functional, flexible, accessible, cost-effective education to the citizens of Nigeria (Adamu, 2017; NUC, 2017). As these HE institutions continue to record success in the provision of distance education, public and private employers perceptions toward ODL graduates changed dramatically. This is because, the key elements of on-campus opportunities are replicated to ODL students online with little or no physical infrastructures and the geographical barriers to accessing HE are removed while the graduates positioned for positive outcomes.

Distance learning graduates are students who received their education through distance mode and graduate with knowledge and skills needed to contribute positively to the workforce. As these students completed the prescribed curriculum and fulfilled all the requirement for their chosen programs, they joined their colleagues who graduated from conventional HE institutions in the labour market as employees in search of paid jobs or an opportunity to establish their own business. Therefore, it's important to understand the dynamics that shaped employers' sentiments in Niger state regarding ODL graduates and how they perceived the quality of these graduates as compared to their colleagues from other institutions.

Despite the global acceptability of ODL program, its flexibility and cost effectiveness, the quality and competitive ability of its graduate in the labour market matters most to prospective employers. Although, it is not clear whether these employers based their concern on earned qualifications from ODL institutions or the generic skills in which the graduates could be able to showcase in the workplace. Though, Lisá et al. (2019) opined that the key issue may not be whether the degree was completed on-campus or on distance mode, but instead about the quality of the institution and thoroughness of the program. Presently, organizations are still nursing reservations regarding ODL graduates perceiving their certificates as inferior and questioning their ability to cope with dynamic job demands (Miglani et al., 2018). While these perceptions continue to linger among employers of labour, Federal and State government in Nigeria find certificates obtained from ODL institutions suitable for entry into labour force and promotion of staff to higher positions. However, Bukaliya and Mubika (2014) clarified that private sector do not share a similar belief.

Consequently, as ODL graduates escaped the dogma of certificate recognition from employers comes the issue of quality of the training received as compared to their peers trained in conventional higher institutions. Aggarwal (2016) opined that quality of training is seen in the learnt skills displayed by graduates in the workplace if employed. It could also mean ability to work with less supervision while reaching the timely target set by the employers. Indeed, quality concerns may not mean much to non-profit organizations like public services and related government parastatals but could mean much to profit oriented organizations. Subsequently, the perceptions of employers regarding ODL graduates might not mean the same when it comes to fresh employment compared to sending their staff for further training.

For fresh employment, Gauvreau et al., (2016) stated that employers of labour question the credibility and expertise of ODL graduates especially in jobs requiring technically oriented skills such as teaching, nursing, engineering, filming and driving. This is based on the belief that these jobs require practically oriented training and a supervised learning by doing to qualify for certification. Thus, learning through distance mode might not support such practically demanding jobs; where it does, the quality of the training could not be compared with those who undergo rigorous conventional training. However, Ofoha and Iwuchukwu (2018) remarked that quality of the institutions measured by its global rankings, academic staff dispositions, quantitative indicators of students' achievement, the employer ratings of graduates, accreditation status and the presence of its activities in the internet can further the extent to which employers respond positively to ODL graduates. For on the job training, Miglani et al., (2018) noted that employers' perception on ODL training could be inversely dependent on employees' motives. For example, employees may wish to further education to obtain a higher qualification either sponsored or on their own without the certificate being necessarily a requirement for promotion. Similarly, employers themselves will sponsor staff through ODL to sharpen their skills and attitude to work by taking advantage of having the staff to work and also study on weekends. In any of these situations, employers' perception toward ODL graduates would invariably be influenced by their inherent motives which could also translate in to attitude formation.

Attitude of employers toward ODL graduates is not alien to their inherent perceptions on the credibility of their certificates earned through the program. Though, Butler (2013) opined that attitude is formed by factors surrounding the nature of ODL program such as standards set for enrolment, calibre of lecturers, quality of teaching, commitment to teaching, examination procedures and in sum, quality assurance mechanisms put in place. Similarly, Bukaliya and Mubika (2014) remarked that how ODL graduates conduct themselves at the interview session could be a precursor to employers' attitude formation. For example, graduates' ability to communicate ideas effectively, manage their temperament while responding to questions and demonstrate capacity to contribute meaningfully in the growth of the organization could stimulate employers' attitude formation. In these situations, many are interviewed but few are found worthy to be employed.

Attitudes are inherent beliefs and could be either positive or negative. Employers' positive or negative attitudes towards employing an ODL graduate will influence the degree to which they accept or reject the candidates (Adeyinka \& Bashorun, 2012). Indeed, Butler (2013) is of the opinion that understanding employers' attitude toward ODL graduates is central to the development of the programme itself and the demand for policy adjustment. Despite the influencing role of employers' attitude toward ODL graduates, it is rarely examined in 
related studies particularly from the African context and Nigeria. This necessitate the need to recapitulate on what the literature covered on employers' perceptions and attitude toward ODL graduates. The review would not only inform the researchers of the variables covered in previous studies and their relevance to the present study, but also the depth of coverage and study locations.

\section{LITERATURE REVIEW}

Related literature was reviewed on employers' perceptions and attitude toward ODL graduates partly to established whether what has been studied on these variables has adequately addressed the research problem under consideration. Furthermore, the review would also justify whether new questions need to be asked to solve the research problem. For example, Bukaliya and Mubika (2014) undertook a study on the perceptions of human resources officers in parastatals on the employability of ODL graduates from the Zimbabwe Open University (ZOU). Ten Human Resources Managers made up the sample through convenience sampling techniques. The study adopted multi-method approach which entailed cross sectional survey, interviews and document analysis to accommodate diverse opinions from various parastatals in Zimbabwe. The data was analyzed using totals and percentages. The findings showed that HRMs in parastatals have employed ODL graduates because of their maturity, diligence and unremitting nature, among other positive attributes. The finding also showed that ODL graduates were of comparable quality to those trained in the conventional tertiary institutions. Similarly, parastatals also perceived ODL graduates as employable due to their enhanced employees`skills and improved job performance.

Ofoha and Iwuchukwu (2018) carried out a study on Employers' Perception and Expectations of Professional Competency of Distance Learning Graduates: A Tracer Study of Nursing Graduates of the National Open University of Nigeria (NOUN). The study employed the descriptive survey design. Participants included 222 NOUN alumni who graduated in nursing programme and a corresponding 222 heads/toplevel managers of the organizations where the graduate nurses were employed. Multiple instruments were used to collect data including competency test, survey questionnaire, and direct observation. Data collected were analyzed using basic descriptive statistics such as frequency counts, percentages, mean, standard deviation and quadrant analysis. The findings show that majority of sampled graduates appeared to possess high level of professional competency in all three competency dimensions measured. A significant proportion of employers seemed to hold positive attitude regarding the graduates.

Lisá, Hennelová, and Newman (2019) conducted a study on comparison between employers' and students' expectations in respect of employability skills of university graduates. The sample of the study involved 27 employers and 534 students from Slovakia. Three hundred and twenty-five companies received an online questionnaire from July 2017 to November 2017. The data was analyzed by JASP 0.8.1.2. statistical program. The result showed that Perceptions of satisfaction showed that students were considerably more satisfied with the level of their skills than employers were. Similarly, employers were most satisfied with the skills of expectation of success, self-confidence and self-presentation, optimism for the future, computer skills, and the conviction that I can finish my job. The study of Bukaliya and Mubika (2014) is of relevance to this study as it established the parastatals perceptions on ODL graduates as employable due to their enhanced skills and improved job performance. However, these perceptions are of human resource officers in Zimbabwe. Could a similar perception be obtained in Nigeria? Additionally, the study findings of Bukaliya and Mubika (2014); Ofoha and Iwuchukwu (2018) were limited to descriptive statistics. Could adding inferential statistics provide a more relevant information? Thus, with the literature reviewed, there seems to be a vast difference in perception of employers regarding distance learning graduates and their attitude toward these graduates. It is therefore, pertinent to study the Perception and Attitude of Employers toward Distance Learning Graduates in the context of Nigerias' Labour Market.

\section{STATEMENT OF THE RESEARCH PROBLEM}

The number of admission seekers into institutions of higher learning is on the surge and conventional schools cannot solely cater for rising need of prospective students as physical infrastructures and human resources are inadequate. Even when these facilities are available, some admission seekers prefer to enrol for distance learning programmes because of their job and family engagements. Distance learning is therefore complementing the conventional university system through the provision of higher education to willing candidates who should be able to compete and contribute to the manpower need of a society in the labour market after graduation.

In developed countries of the world, the labour market is opened to all graduates without any form of discrimination on the basis of types of institution attended. In these countries, ability to meet up with job productivity demands, skills and competencies possessed by a job applicant is of paramount importance. However, in Nigeria, there has been a great controversy surrounding the quality of distance learning graduates. For instance, there is a trending debate on whether distance learning graduates should be allowed to participate in the mandatory one-year national youth service. Also, it is being debated whether law graduates from such institutions should be allowed to proceed for the bar programme at the Law School. These arguments, debates and controversies bother on employability skills possessed by graduates from these institutions.

In the face of these debates, the researchers deem it necessary to investigate the perception and attitude of employers of labour who currently have graduates from these institutions in their payroll Niger state instead of these needless public debates. Having employed graduates from both conventional and distance learning institutions, do they find them comparable in terms of employability skills, competencies and job deliverables? Hence, this study was carried out to investigate the perception and attitude of employers of labour toward distance learning graduates in Niger State, Nigeria.

\section{RESEARCH QUESTIONS}

The following research questions guided the study:

1. What is the mean perception scores of employers of labour about distance learning graduates?

2. What is the mean attitude scores of employers of labour toward distance learning graduates? 
3. What is the difference in the mean perception scores of public and private employers of labour about distance learning graduates?

4. What is the difference in the mean attitude scores of public and private employers of labour towards ODL graduates?

\section{RESEARCH HYPOTHESES}

The following null hypotheses were tested in the study:

HO1: There is no significant difference between the perception of public and private employers of labour about distance learning graduates.

HO2: There is no significant difference in the attitude of public and private employers of labour toward distance learning graduates.

\section{METHODOLOGY}

This study adopted the descriptive survey design. Survey research is considered appropriate when it is required to study the characteristics of a given population by quantitatively collecting and analysing statistical data obtained from a sample that satisfactorily represents them (Creswell \& Creswell, 2018). While a descriptive survey is carried out in situations where identified findings of a studied population is to be described. Hence, the methodology used in this study involved the use of questionnaire to obtain the needed data from respondents (employers of labour) on their perception and attitude towards graduates of distance learning institutes in labour market.

\section{Participants}

The population of this study consists of all human resource personnel from both private and public organizations within the study area whose job designation entails being responsible for employment, recruitment, and placement of job applicants in Niger State. The sample of the study comprises of 100 employers of labour. A multi-stage sampling technique was employed in selecting respondents for this study. Firstly, purposive sampling procedure was used to identify 50 establishments and industries based on their tracked record as organizations that recruited and employed many graduates within the last ten years. Thereafter, the 50 establishments identified were classified into either government or private organizations. Simple random sampling technique was then used to select 10 establishments from each of the government and private organizations, from where five management staff and recruitment officers were sampled. Hence, there were 50 participants each from private and public establishments consisting of manufacturing, agriculture, technology, heath among others.

\section{Data Collection and Analysis}

Researchers-developed a questionnaire entitled 'Perception and Attitude of Employers of Labour toward Distance Learning Graduate (PAELDLG) and was used as instrument for data collection. It consists of section A, B \& C. Section A focused on respondents' demography (name of organization, duty, year of experience and rank). Section $B$ comprises of 12 items while Section C comprises of 7 items and they respectively focused on respondents; perception and attitude towards distance learning graduates. The items of the questionnaire were developed from issues that emanated from the literature. These items were believed to have adequately represented the perception and attitude of employers of labour towards distance learning graduates in Niger State.

\section{The Scale}

The questionnaire was validated by three distance learning experts and two behavioural psychology specialists. Their comments and suggestions were used to improve on the final version of the instrument. Thereafter, a pilot test was conducted on 10 randomly selected respondents that have similar characteristics with the sample of the study and within the study area. The result of the analysis was used to determine the internal consistence of the questionnaire. Cronbach alpha's formula was used and 0.88 (for Perception construct) and 0.74 (for Attitude construct) were obtained. Hence the validity and reliability of the instrument were ensured before proceeding to field for data collection.

The data was collected with printed type questionnaire and was administered to the respondents in their respective organizations. To facilitate the process of data collection, four research assistant were recruited to administer the instrument. The data collection process was completed within four weeks. During the process, ethical considerations such as confidentiality, integrity was ensured. The data collected from the administered questionnaires were analysed using descriptive and inferential statistics with the aid of Statistical Package for Social Science (SPSS, Version 23). Two of the four research questions were answered using Mean and Standard Deviation while the other two were translated to null hypotheses which were tested using independent sample t-test.

A five-point rating scale of Strongly Agree (SA, 5 points), Agree (A, 4 points), Undecided (U, 3 points), Disagree (D, 2 points) and Strongly Disagree (SD, 1 point) was used in weighing responses to items in the questionnaire. Research questions were answered using means. Therefore, any item with weighted mean response below 3.0 was considered disagreement (negative perception/attitude) while a mean response of 3.0 and above was considered as agreement (positive perception/attitude). Also, alpha value of 0.05 was used as benchmark for accepting or rejecting hypothesis in which, hypothesis whose t-test analysis results in alpha value of 0.05 and above was accepted while hypothesis whose t-test analysis results in alpha value below 0.05 was rejected.

\section{RESULTS}

In order to determine the perception of employers of labour about distance learning graduates, responses of 100 respondents to the 12 questionnaire items were collated and analysed as presented in Table 1.

Table 1 shows the mean and standard deviation of responses on the perception of employers of labour on distance learning graduates. The table reveals that the mean score of responses to each of the items (ranges from 3.73 to 4.57 ) was consistently above the decision mean of 3.0. A grand mean score of 4.00 was obtained for the 12 items. Since, the cumulative mean is above the decision mean, this implies that respondents are in agreement with the statements. Hence, employers of labour in Niger State have positive perception about distance learning graduates. 
Table 1. Mean and standard deviation of employers' responses regarding their perception of distance learning graduates

\begin{tabular}{|c|c|c|c|c|c|}
\hline $\mathbf{S} / \mathbf{N}$ & Items: Do Distance Learning Graduates; & $\mathbf{N}$ & $\overline{\boldsymbol{X}}$ & SD & Decision \\
\hline 1 & Possess the ability to work productively even while under pressure & 100 & 3.73 & 0.874 & Agree \\
\hline 2 & Possess the potentials that are needed to carryout dual responsibility (multiple tasking) & 100 & 4.04 & 0.777 & Agree \\
\hline 3 & $\begin{array}{l}\text { Possess the ability to find and access new information via the internet in order to improve their rate productive at } \\
\text { work place. }\end{array}$ & 100 & 4.57 & 0.590 & Agree \\
\hline 4 & Possess the basic skills required in their major field of specialization & 100 & 4.03 & 0.745 & Agree \\
\hline 5 & Possess the ability to take initiative and work with little or no supervision. & 100 & 3.99 & 0.732 & Agree \\
\hline 7 & Possess the quality of team working spirit with their co-workers. & 100 & 4.13 & 0.580 & Agree \\
\hline 8 & Accept responsibility without complaining and are accountable & 100 & 3.92 & 0.748 & Agree \\
\hline 9 & Align work goals with the mission and vision of accomplishing the company's goal employer & 100 & 3.99 & 0.643 & Agree \\
\hline 10 & Possess the ability to learn the required technology and use appropriately & 100 & 4.01 & 0.703 & Agree \\
\hline 11 & Adapt easily and are flexible in coping with changing work environment & 100 & 3.91 & 0.726 & Agree \\
\hline \multirow[t]{2}{*}{12} & Possess the basic communication skills that can promote better understanding among other business associates & 100 & 3.96 & 0.751 & Agree \\
\hline & Grand Mean & & 4.00 & & Agree \\
\hline
\end{tabular}

Decision mean $=3.0$

Table 2. Mean and standard deviation of responses regarding employers of labour's attitude toward distance learning graduates

\begin{tabular}{|c|c|c|c|c|c|}
\hline $\mathbf{S} / \mathbf{N}$ & Items & $\mathbf{N}$ & $\overline{\boldsymbol{X}}$ & SD & Decision \\
\hline 1 & Treated with equal right based on their performance at work and not based on the institution they graduated from & 100 & 4.60 & 696 & Agree \\
\hline 2 & Based on same salary scale as others and other allowances will be based on their input at work (earn as you work). & 100 & 4.01 & 1.367 & Agree \\
\hline 3 & Employed based on performance during interview and placed on their appropriate cadre & 100 & 4.53 & .810 & Agree \\
\hline 4 & Allowed to get access to the company's employment platform and selection will be based on merit. & 100 & 4.54 & 642 & Agree \\
\hline 5 & Enlisted for further training and promotion courses as at when due without any bias & 100 & 4.48 & .870 & Agree \\
\hline 6 & $\begin{array}{l}\text { Given a free hand to utilize their potentials when and where necessary and teamwork spirit will be encouraged } \\
\text { among employees so as to avoid discrimination of any kind }\end{array}$ & 100 & 4.68 & .79 & Agree \\
\hline \multirow[t]{2}{*}{7} & Promoted based purely on merit and as at when due. & 100 & 4.60 & .65 & Agree \\
\hline & Grand Mean & & 4.49 & & Agree \\
\hline
\end{tabular}

Decision mean $=3.0$

Table 3. t-test comparison of responses on perception of public and private employers of labour about distance learning graduates

\begin{tabular}{cccccccc}
\hline Organization & $\mathbf{N}$ & Mean & S.D & Df & t-value & p-value & Decision \\
\hline Public & 50 & 48.73 & 5.406 & \multirow{2}{*}{98} & \multirow{2}{*}{$1.137 \mathrm{~ns}$} & \multirow{2}{*}{0.258} & \multirow{2}{*}{ Accepted } \\
\hline Private & 50 & 47.60 & 4.439 & & & & \\
\hline
\end{tabular}

NS: Not Significant at 0.05 alpha level

In order to determine the attitude of employers of labour toward distance learning graduates, responses of the 100 respondents to the seven questionnaire items were collated and analysed as presented in Table 2 .

Table 2 shows the mean and standard deviation of responses on employers of labour's attitude toward distance learning graduates. The table reveals that the mean score of responses to each of the items (ranges from 4.01 to 4.68) was consistently above the decision mean of 3.0. A grand mean score of 4.49 was obtained for the seven items. Since, the cumulative mean is above the decision mean, this implies that respondents are in agreement with the statements. Hence, employers of labour in Niger State have positive attitude toward distance learning graduates.

Hypothesis One: There is no significant difference between the perception of public and private employers of labour about distance learning graduates.

To determine whether significant difference exists in the perception of employers of labour about distance learning graduates based on type of organization, the responses from public and private organizations are collated separately and compared using independent sample t-test. The result of the analysis is presented in Table 3.
Table 3 shows the result of independent sample t-test comparison of mean responses of employers of labour in public and private organizations on their perception about distance learning graduates. The table reveals that mean scores of Public (Mean $=48.73, \mathrm{SD}=5.406)$ and Private (Mean $=47.60, \mathrm{SD}=4.439)$ organizations are not significantly different $(t=1.137, \mathrm{df}=98, \mathrm{p}>0.05)$. Hence, hypothesis one was accepted. This implies that no significant difference exists in the perception of employers of labour in public and private organizations in Niger State about distance learning graduates. Explicitly, employers of labour in public and private organizations in Niger State shared a positive perception toward distance learning graduates.

Hypothesis Two: There is no significant difference in the attitude of public and private employers of labour toward distance learning graduates.

Table 4 shows the result of independent sample t-test comparison of mean responses of employers of labour in public and private organizations on their attitude towards distance learning graduates. The table reveals that mean scores of Public (Mean $=40.00, \mathrm{SD}=8.096$ ) and Private (Mean $=44.38, \mathrm{SD}=4.570)$ organizations are significantly different $(t=3.454, \mathrm{df}=98, \mathrm{p}<0.05, d=.66)$. the finding indicates that the difference between the attitude of public and private employers of 
Table 4. t-test comparison of responses on attitude of public and private employers of labour about distance learning graduates

\begin{tabular}{ccccccccc}
\hline Organization & N & Mean & S.D & df & t-value & p-value & Cohens' d & Decision \\
\hline Public & 50 & 40.00 & 8.096 & \multirow{2}{*}{98} & \multirow{2}{*}{$3.454^{*}$} & \multirow{2}{*}{0.01} & \multirow{2}{*}{.66} & \multirow{2}{*}{ Rejected } \\
\hline Private & 50 & 44.38 & 4.570 & & & &
\end{tabular}

*Significant at 0.05 alpha level

labour towards distance learning graduates did not happen by chance. Hence, hypothesis two was rejected. Further Cohen's' $d$ effect size value revealed a "medium" effect $(d=.66)$. This implies that significant difference exists in the attitude of employers of labour in public and private organizations in Niger State towards distance learning graduates. Overtly, private employers of labour would be more open to distance learning graduates for employment than the public employers.

\section{DISCUSSION OF FINDINGS}

The findings of research question one and the corresponding null hypothesis revealed that employers of labour have positive perception about distance learning graduates. Though, this finding is a revelation of a core perception of employers of labour generally regarding distance learning graduates, it was further substantiated along public and private organizations and indicated no significant difference. The findings imply that both public and private employers of labour are comfortable with the certification, level of training received, competency of the graduates and are ready to employ them in their respective organizations. The finding was supported by Bukaliya and Mubika (2014) who showed that parastatals perceived ODL graduates as employable due to their enhanced employees skills and improved job performance and were of comparable quality to those trained in the conventional tertiary institutions. Furthermore, the finding might not be surprising because, both public and private organizations have distance learning graduates either as fresh employees or as in-service trainees. As such, their productivity is well known and could therefore be attributed to this finding. The finding was supported by Lisá et al., (2019) whose result indicated that employers were most satisfied with the skills of expectation of success, self-confidence and selfpresentation, optimism for the future, computer skills, and the conviction that I can finish my job. Additionally, distance learning graduates are ICT savvy as postulated by the finding of Lisá et al., (2019) and have been using it efficiently having successfully undergone distance learning programmes where ICT were the medium through which resources are deployed to them. As such, ICT competency among ODL graduates could be a bridging gap when compared with conventional HE institutions graduates and also a factor responsible for employers' positive perception about these graduates.

The findings of research question two and the corresponding null hypothesis revealed that employers of labour have positive attitude towards ODL graduates. Nonetheless, employers of labour in private organizations had submitted a higher level of positive attitude than public organisations' employers. This could be attributed to how private employers enjoy sending their employees for further training through ODL without interfering with their daily work schedules. Similarly, it could be that the employers in private sector observed the impact of training their staff received from ODL in terms of paradigm shift, new skills and general improvement in the organisational growth. To further understand the differential levels of attitude among public and private employers of labour, a hypothesis was tested and yielded a significant difference with a medium effect size. Conventionally, for private organization employers of labour to report high level of positive attitude toward ODL graduates, they might have tested them in various stages of their production lines. This is based on the belief that private employers have robust evaluative measures than public sector because, they are profit oriented. The finding was supported by the earlier finding of Bukaliya and Mubika (2014) whose result showed that HRMs in parastatals have employed ODL graduates because of their maturity, diligence and unremitting nature, among other positive attributes. The finding was also supported by Ofoha and Iwuchukwu (2018) whose findings showed that majority of sampled graduates possess high level of professional competency in all three competency dimensions measured and a significant proportion of employers held a positive attitude regarding the graduates.

\section{CONCLUSION AND FUTURE WORK}

Employers of labour in Niger State have positive perception towards ODL graduates. This could be translated to mean that employers had a prior experience with ODL graduates either at industrial training level, teaching internship or as employees. As such, they have a feel of what they can deliver to strengthen their organizational growth. Furthermore, employers are confident with the level of training received by ODL graduates and are ready to employ them. Where the ODL graduates are employed, employers do not find them worthless but comfortable with their skill display. To further validate the perception of employers on ODL graduates, both public and private sector share similar perception. The similarities in perception of public and private sector employers showed that ODL graduates are comparable to their counterparts graduated from conventional full time HE institutions. Similarly, employers of labour have positive attitude towards ODL graduates. However, the level of attitude accorded to ODL graduates was not the same among employers of labour in public and private sector with more positive attitude emanated from private sector employers. This implies that private employers of labour would not mind employing distance learning graduates in their future recruitments.

The novelty of this study is that employers of labour are more concern on the generic skills in which the graduates could be able to showcase in the workplace than the earned qualifications, certifications and the type of institutions attended. This is an information to prospective employers, a direction to the ODL training centres, an applaud to ODL instructors and an encouragement to ODL candidates. This expression of perceptions and attitude of employers of labour toward ODL graduate would further enlighten the general public to consider ODL training centres as alternative to attending conventional HE institutions. In addition to creating awareness for their comparative advantage, potential candidates opting for ODL programs can reduce pressure for Universities, Polytechnics, Colleges of Education, as well as institutes that prepare candidates for professional courses. This will manifest in form of admitting a manageable number of students that fall 
within the carrying capacity of lecture halls, classrooms, students' hostels, libraries and ICT laboratories.

Despite these novel contributions uncovered by the findings of this study, it suffers from limitations. For instance, the data collected for this study was limited to human resource personnel from private and public organizations in Niger State. Further studies can expand the scope by identifying other establishments outside Niger State. Another limitation of the study was that of collecting quantitative data using questionnaire as instrument. A follow-up study can consider adding a qualitative approach by developing interview schedules to interview the administrative heads of the identified establishments. Even with these limitations, the study had substantiated the perceptions and attitude of employers of labour toward ODL graduates in Niger State while equally supporting similar studies conducted outside Nigeria.

\section{RECOMMENDATIONS}

Based on the findings that emanated from this study, the following recommendation were made

1. Since employers of labour in Niger State have positive perception towards ODL graduates, government should expand the existing ODL and establish new ones to reduce the load on conventional institutions and curtail the problem of access to HE in Nigeria.

2. Considering how positively indifferent employers of labour in public and private sector perceived ODL graduates, the ODL facilitators should use these findings to build courage among prospective ODL students.

3. As employers of labour submitted a positive attitude toward ODL graduates, the government should increase awareness on the existence of ODL for it to be used as a comparable alternative to conventional $\mathrm{HE}$ in Nigeria. This will further curb the menace of accessibility to HE and increase opportunity for in-service trainees, adults, women, physically challenged and those from remote locations to access education at their door step.

4. As private employers bowed to a more positive attitude toward ODL graduates, is a postulation of the strength of the program. Therefore, the government should deploy state of the art facilities such as tablet computers, steady internet, wireless communication system and a specialized interactive learning management system software for ODL centres.

\section{REFERENCES}

Adamu, A. U. (2017, July 26). NOUN: Student population hits 400,000 Blueprint. Retrieved from https://www.blueprint.ng/nounstudents-population-hits-400000/
Adeyinka, T., \& Bashorun, M. T. (2012). Attitude of undergraduate students towards computer-based test (CBT): A case study of the university of Ilorin, Nigeria. International Journal of Information and Communication Technology Education, 8(2), 33-45. https://doi.org/10.4018/jicte.2012040103

Aggarwal, S. (2016). Central pillar of employability: Skill development. Imperial Journal of Interdisciplinary Research, 2(3), 27-39.

Bukaliya, R., \& Mubika, A. K. (2014). Exploring Parastatal Employers' Perceptions of Open and Distance Learning Graduates: The Perspective of the Human Resources Managers/Officers. International Journal of Research in Business Studies and Management, 1(2), 27-35.

Butler, D. L. (2013). The impact of computer based testing on student attitudes and behaviour. The Technology Source, 10 (4), 34-35.

Creswell, J. W., \& Creswell, J. D. (2018). Research Design: Qualitative, Quantitative, and Mixed Method Approaches (5th Ed.). New Delhi, India: Sage Publications.

Federal Republic of Nigeria (FRN) (2013). National Policy on Education (1st Ed.). Lagos: NERC, Press Yaba.

Gauvreau, S. A., Hurst, D., Cleveland-Innes, M., \& Hawranik, P. (2016). Online professional skills workshops: Perspectives from distance education graduate students. The International Review of Research in Open and Distributed Learning, 17(5), 19-28. https://doi.org/10.19173/irrodl.v17i5.2024

Lisá, E., Hennelová, K., \& Newman, D. (2019). Comparison between employers' and students' expectations in respect of employability skills of university graduates. International Journal of Work-Integrated Learning, 20(1), 71-82

Miglani, A., Awadhiya, A. K., Singh, N., Gowthaman, K., \& Kansal, G. (2018). Policy Recommendations from Employers for Enhancing Skills Through ODL. Turkish Online Journal of Distance EducationTOJDE, 19(4), 64-75. https://doi.org/10.17718/tojde.471653

NUC. (2017). List of approved distance learning centres. Retrieved from http://nuc.edu.ng/distance-learning-centers/

Ofoha, D., \& Iwuchukwu, O. (2018). Employers' Perception and Expectations of Professional Competency of Distance Learning Graduates: A Tracer Study of Nursing Graduates of the National Open University of Nigeria (NOUN). Open Praxis Journal, 10(3), 265-278. https://doi.org/10.5944/openpraxis.10.3.796

Papadakis, S., Kalogiannakis, M., Sifaki, E., \& Vidakis, N. (2019). Evaluating Moodle use via Smart Mobile Phones. A case study in a Greek University. EAI Endorsed Transactions on Creative Technologies, 5(16). https://doi.org/10.4108/eai.10-4-2018.156382

Rahman, H. (2014). The role of ICT in Open and Distance Education. Turkish Online Journal of Distance Education, 15(4), 162-169. https://doi.org/10.17718/tojde.47700

UNESCO (United Nations Educational, Scientific and Cultural Organization). (2016). Global education monitoring report 2016: Education for people and planet, creating sustainable futures for all. Paris: United Nations Educational, Scientific and Cultural Organization. Retrieved from http://unesdoc.unesco.org/images/0024/002465/ 246501e 